\title{
Surface water pollution risk assessment of wadis, Mekerra and Saïda, in the North-Western of Algeria
}

\author{
Ahmed Guenfoud1, 2, Mohamed Benyahia ${ }^{3}$ and Abdelkader Bouderbala2* \\ ${ }^{1}$ Laboratory Ecodevelopment spaces, Faculty of nature and life, University Djillali Liabès, Sidi Bel \\ Abbès - Algeria.E-mail: guenfoud_ahmed@yahoo.fr \\ 2 Departement of Earth Sciences, Faculty of Nature, Life \& Earth Sciences, PRAVDURN Laboratory, \\ University Djilali Bounamaa, Khemis Miliana - Algeria. \\ ${ }^{3}$ Laboratory Ecodevelopment spaces, Faculty of nature and life, University Djillali Liabès, Sidi Bel \\ Abbès - Algeria. E-mail: benya133@yahoo.fr \\ * E-mail: bouderbala.aek@gmail.com
}

Keywords: Mactaa's basin, Mekerra and Saïda wadis, organic pollution, Sidi-Bel-Abbes and Saïda, OPI, MQI.

\begin{abstract}
Considered as the main stream of hydrographic network of Mactaa's basin, in the west highlands of Algeria, both wadis, Mekerra and Saïda, are affected by pollution which is generated by anthropogenic activities. Makara and Saïda wadis cross the urban areas of Sidi-Bel-Abbes and Saïda respectively, in the west of Algeria, which constitute a real problem of human safety. In order to identify the pollution state on these wadis, samples have been collected during three periods of time (June 2011, July 2012 and April 2013) in the goal to characterize the physico-chemical and bacteriological quality of surface water.Results obtained describe clearly the existence of chemical and organic pollution in both wadis at high levels of calcium, magnesium, chlorides, nitrates, nitrites, phosphate, DBO5 and dissolved oxygen. The evaluation of organic pollution index (OPI) confirmed that there is a high organic pollution, upstream, which increases with high water passage towards urban areas of both cities (OPI).The bacteriological analysis results obtained show presence of high contents of faecal bacteria contamination (total coliforms (TC), faecal coliforms (TC) and faecal streptococci(FS))principally in wadi Saïda. The relationship between FC/FS justifies the predominance of human origin than of animal as source of contamination. While, the determination of microbiological quality index (MQI), for each wadi, confirms degradation of microbiological quality by the faecal pollution, mainly in Saïda urban area.
\end{abstract}

\section{Introduction}

Water resources whatever surface or ground water have an important impact in socio-economic activities development and even in the environmental system of the entire world. Semi-arid and arid regions are facing water shortage due to the irregularity of rainfall, where the scarcity threshold fixed by the World Bank is of $1000 \mathrm{~m} 3 / \mathrm{hab} /$ year (Maliki, 2006).This situation became a major concern among those last years for several countries, in order to ensure water resources in perennial and sufficient for consumers (population, agriculture, and industry), face to the strong population growth and the climatic conditions (climate change and its consequences hydrological systems). This issue does not only limit the water resource quantity but also affect its quality; hence it is important to manage this resource before any uses. Although water quantity covering our planet is remarkable (13 600 million $\mathrm{km}^{3}$ ), only $0,014 \%$ is fresh water that 
used by human. If this quantity is sufficient to respond the humanity's future need, the quality of water will be in good conditions, which is a great challenge for our world (Saad et al., 2007). In fact, water quality is generally generated by anthropogenic activities, and it is the major cause of pollution problems of water and of environment now (Achahbar 2020). Studies around the world and Algeria showed that surface water quality is really suffered during the last years, with high deterioration due to various contaminants leading an impact on flora and fauna (Boudoukha et al., 2014; Bouderbala $2019 a \& b)$. At this, we added the reduction of rainfall, generally extend the drought. In fact, industrial, agricultural, or urban activities are the possible sources that affect the change in water quality and turn it unfit for any use. This is the case of urban and suburban areas crossed by rivers and watercourses, whenthey receive discharges of different kinds of wastewater.

Mekerra and Saïda Wadis represent two main natural channels in the superficial hydrographic network of the great watershed of Mactaa in the west of Algeria of surface about $14389 \mathrm{~km}^{2}$. These two wadis drain a significant surface in Macta (about $32 \%$ of the total surface) and contribute supplying water for Fergoug and Ouizert dams in Mascara; however, these dams are generally exposed to double problems, quantity, and quality. The reductions of the volumes are often due to the siltation phenomena, and the degradation of water quality are mainly due to the impact of a different kind of pollution, such as wastewater discharge. The major problem of environmental degradation is public health. So, the main purpose of the present work is the assessment of water quality of both wadis (Mekerra and Saïda) that crossing the two cities of Sidi-Bel-Abbes and Saïda. We are focusing on physico-chemical and bacteriological parameters. In order to achieve our goal, some methods have been used in order to highlight the overall quality of water and its spatio-temporal evolution in both watercourses studied.

\section{Description of the study area}

Holding geostrategic positions in High Lands (West of Algeria) given a considerable advantages in resource matter such as, hydrological resource, agricultural, ecological, tourist, historic, and industrial) for both regions (Sidi-Bel-Abbes and Saïda). These areas are have a surface of $9150,63 \mathrm{~km}^{2}$ and of $5536,73 \mathrm{~km}^{2}$ respectively $(0,62 \%$ of the total national territory) and a global population estimated at 700.000 inhabitants in 2010, where the majority is concentrated in these two cities(DPPT2011). These cities are crossed by the most important watercourses in the west of Algeria, the first one is Wadi Mekerra (Fig. 1) which has its source from Djebel Timizine in the South-East of Ras-el-Ma, and crosses the city of Sidi-Bel-Abbes in the downstream part, where it gathers with wadi Samo and becomes wadi Mebtouh (Benyahia et al.,2011). Its watershed covers a surface area of $4102 \mathrm{~km}^{2}$ with an elongated form from South to North, and relief is qualified very strong according to Orstom classification ( $\mathrm{Ds}=548 \mathrm{~m}$ ) (Bourek, 2010). During the rainy period, the annual run-off average of wadi Mekerra can reach 42 million $\mathrm{m}^{3}$ (Guenfoud, 2009). 
The second watercourse called Wadi Saïda, represents the extension of wadi Tebouda, and has a source from the south of the watershed, where it obtains its water supply from the great Tebouda source, where it is oriented from South to North (Dahmani, 2016). There are also several Karstic water sources which supply this wadi such as antique Saïda, Ain el Baida... etc. (Khaldi, 2005). However, the drought and climate variation that knows this region in last recent decades, as well as human activities, have been negative impacts on water resources. Its watershed covers an area of $543,7 \mathrm{~km}^{2}$ and a perimeter of $104 \mathrm{~km}$ (Hachemaoui, 2007).

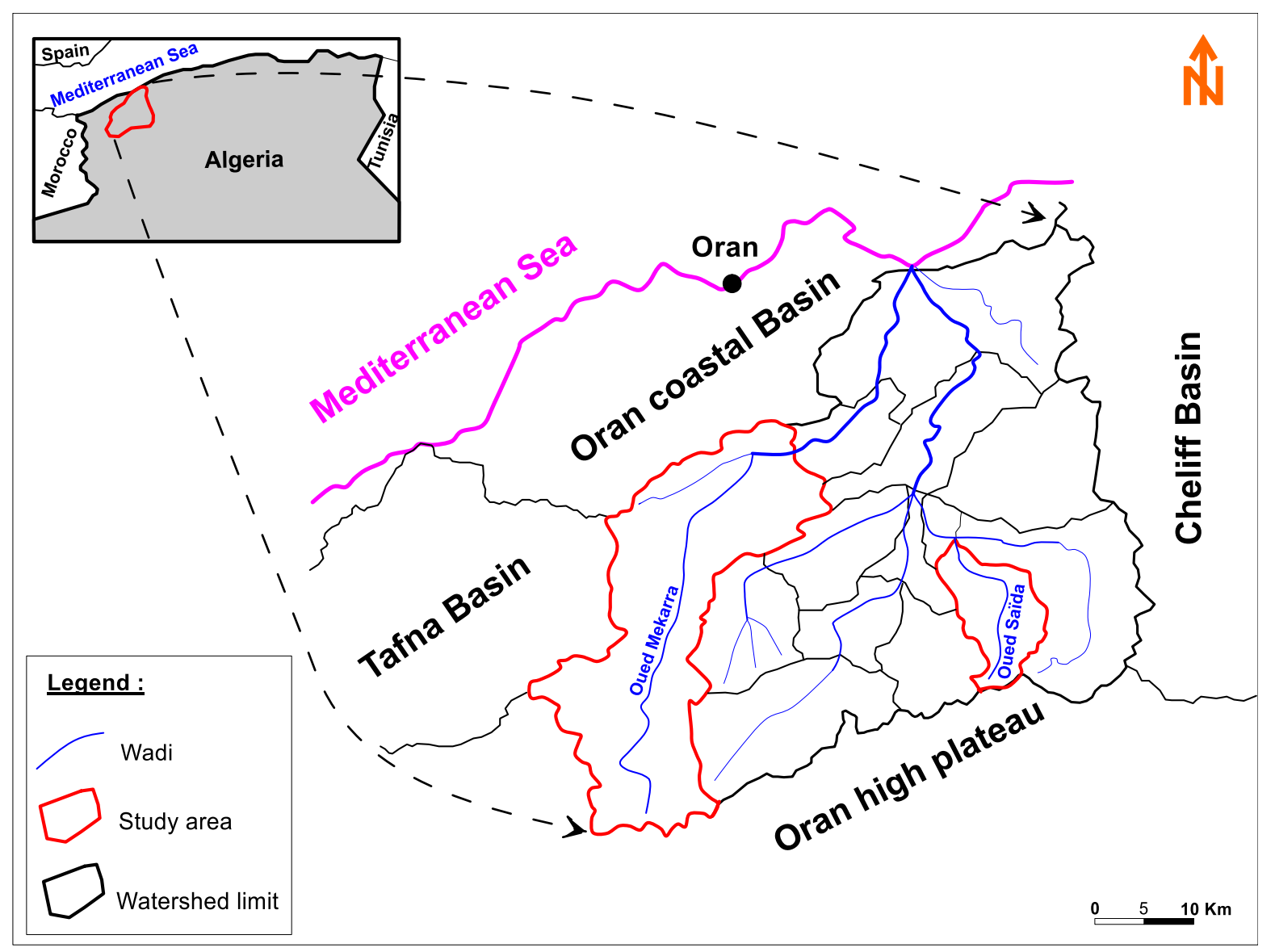

Figure. 1. Location of the two watersheds of wadis Mekerra and Saïda (Meddi et al., 2009) (Modified)

\section{Materials and Methods}

\subsection{Sampling}

Water samples have been taken from the Mekerra and Saïda watercourses that crossing the cities of Sidi-Bel-Abbes and Saïda respectively, at three (03) significant points based on the accessibility to sampling water from watercourse. These sampling points are taken from downstream to upstream of each watercourse:

The three sampling points of the first watercourse crossing the city of Sidi-Bel-Abbes (Fig. 2) are: The first sample point (M1) is located in the west of the city, near to the wildness discharge which has an impact on surface water quality. The second sample 
point (M2) is located in centre of the city, in the wastewater discharge. While, the third one (M3) is located in the upstream of Sidi-Bel-Abbes city, near to the wastewater treatment plant of Sidi-Bel-Abbes, which is intended to domestic wastewater.

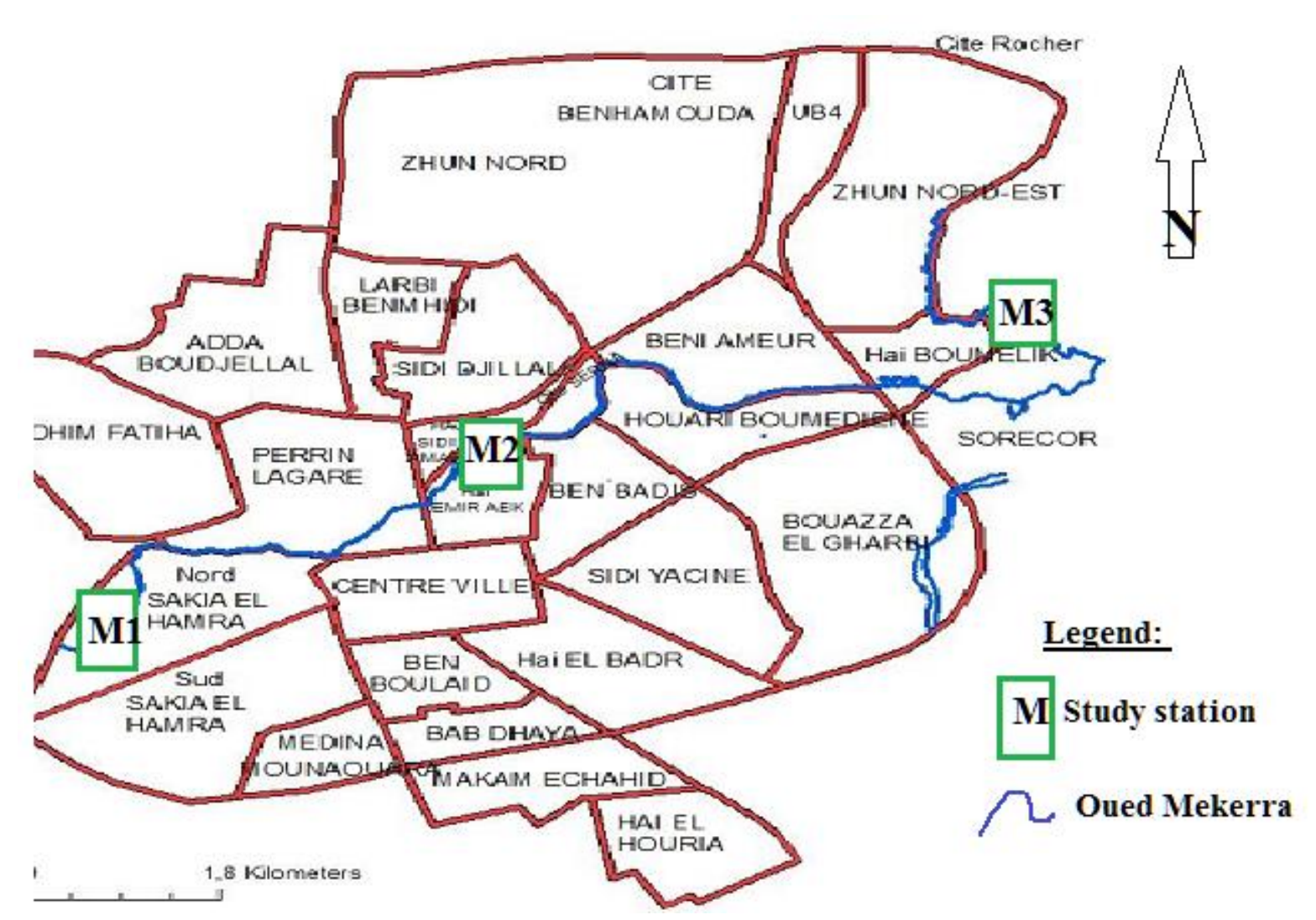

Figure. 2. Location of sampling points in Wadi Mekerra (Tahar ,2013) (modified)

The three sample points of the second watercourse crossing the city of Saïda (Fig. 3) are: The first one (S1) is positioned in the south of Saïda city, in the forest recreation ground of Touta, where wadi Saîda receives water from the great source of Tebouda with (average flow of $30 \mathrm{l} / \mathrm{s}$ in normal conditions), and from the karst sources near this area, and also from the treated water discharge, which comes from wastewater treatment plant of Ain El Hadjar. The second sample point (S2) is situated in the city centre, in the dense urban zone, mostly receiving domestic wastewater and solid discharges (households waste, worksite waste). While, the third sampling point is located near Saïda city limits, near to the village of Rebahia, and nearby the industrial installations. In this sector, wadi Saïda receives domestic and industrial wastewater. 


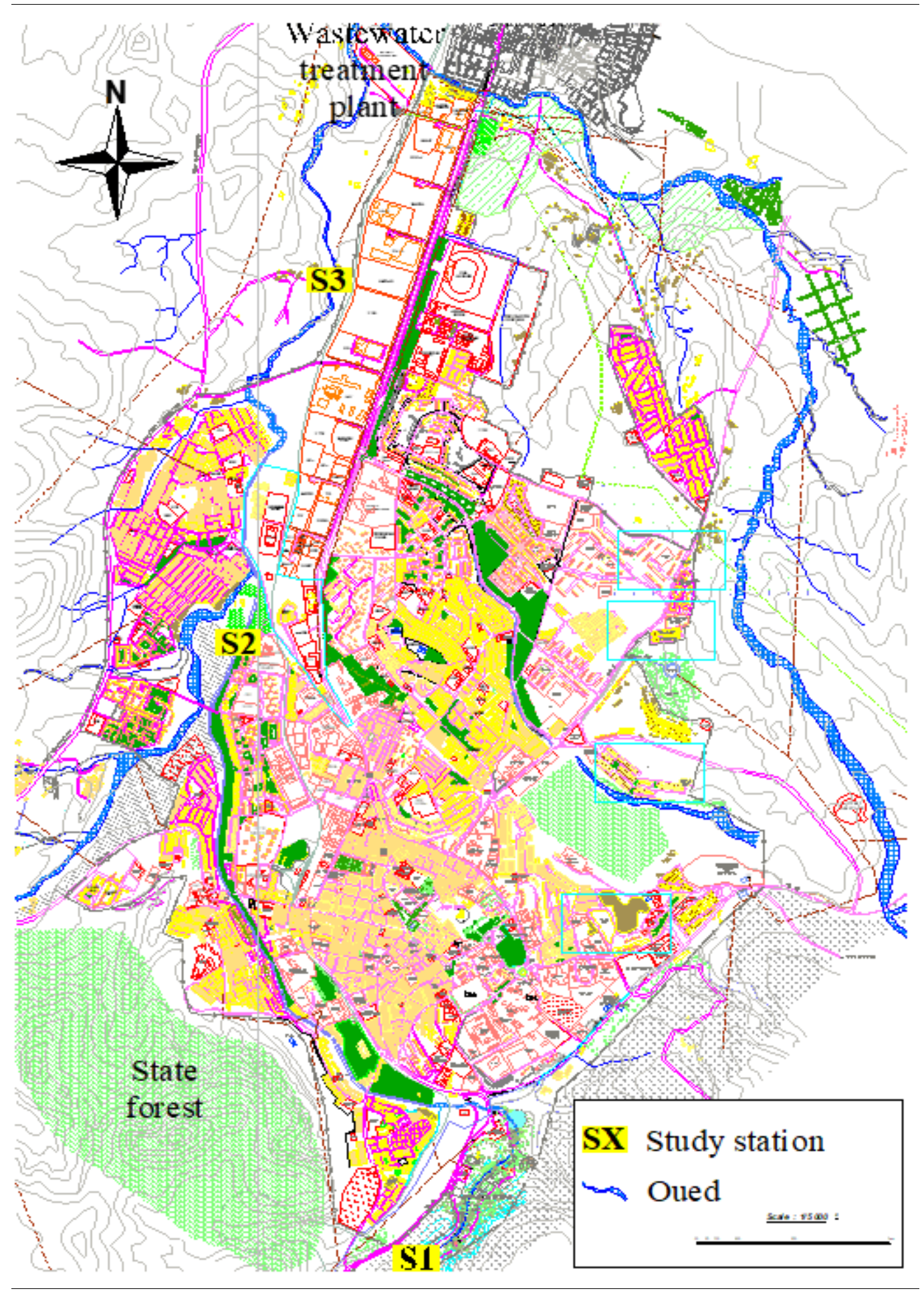

Figure. 3. Location of sampling points in Wadi Saïda (Kerkeb,2011) (modified)

\subsection{Physico-chemical analysis}

Samples have been collected during periods of June 2011, July 2012 and April 2013 in the two wadis (Sidi-Bel-Abbes and Saïda). For each sampling, temperature and pH were measured in-situ. While, the water sample has been kept at $4{ }^{\circ} \mathrm{C}$ in an iced cooler for storage during transport to the laboratory of chemistry in Sidi-Bel-Abbes University, where they were analyzed within 24 hours. The analysis methods adopted for the 
determination of calcium, $\left(\mathrm{Ca}^{2+}\right)$ magnesium $\left(\mathrm{Mg}^{2+}\right)$, Chlorides $\left(\mathrm{Cl}^{-}\right)$, nitrate $\left(\mathrm{NO}_{3}^{-}\right)$, nitrite $\left(\mathrm{NO}_{2}{ }^{-}\right)$, sulphate $\left(\mathrm{SO}_{4}{ }^{2-}\right)$, ortho-phosphate $\left(\mathrm{OP}_{4}^{3-}\right)$ and dissolved oxygen $\left(\mathrm{O}_{2}\right)$, dry residue (DR) were those cited by Rodier (2009). For the biological demand in oxygen during five days (BOD5), the method used was that of ISO (3815-2003).

\subsection{Micro bacteriological analysis}

Bacteriological analyses have been focused on pollution indicators which gather faecal contamination bacteria such as: total coliforms, (TC), faecal coliforms (FC), streptococci faecal (SF), Total Mesophile Aerobic Germ (TMAG) at $22^{\circ} \mathrm{C}$ and $37^{\circ} \mathrm{C}$. Analyses were conducted according to the same frequency of that of physico-chemical, and samples were collected during the periods of March 2011, September 2012 and May 2013. The counts of TMAG were made by seeding in the surface on the agar medium. The reading was done after 48 hours of incubation at $37^{\circ} \mathrm{C}$ or after 72 hours of incubation at $22{ }^{\circ} \mathrm{C}$. Totals and faecal coliforms have been done by seeding in liquid medium (colimetry) the same method for streptococci. Serial dilutions have been done for all samples to facilitate counting. Used methods for the evaluation of bacteriologic quality are those recommended by Rodier (2009).

\section{Results and discussion}

\subsection{Assessment of physico-chemical quality}

Physico-chemical parameters are influenced by spatio-temporal variations and by anthropogenic activities which change consequently water quality (Karrouch et al., 2017). The recorded temperatures in wadis Mekerra and Saïda show a low variation from one period to another. The highest values are recorded in June 2011 and July 2012, while the lowest are observed in April 2013. However, the spatial variation of average temperatures (Fig. 4) indicate variation from downstream towards upstream for each Wadi with a low-values in the intermediate stations (M1: $22.03^{\circ} \mathrm{C}$ and $\mathrm{S} 1: 21,83^{\circ} \mathrm{C}$ ). This variation of temperatures maybe due to: the stream morphology, soil nature, and the different types of discharge, flow rate, ambient temperature, agitation or stagnation, solar radiation and vegetation on these two watercourses. The observed values of $\mathrm{pH}$ (Fig. 4) from downstream to upstream show that water of both wadis have a neutrality range of $\mathrm{pH}$ (from 6,5 to 8,5 ). Regarding, electrical conductivity (EC) which give idea about water mineralization degree (Bremond et Perrodon, 1979), the measured EC in the three points in each wadi, indicates an increase from upstream to downstream in general (Fig. 4), with values ranging from $2074 \mu \mathrm{S} / \mathrm{cm}$ to $2531 \mu \mathrm{S} / \mathrm{cm}$ in wadi Mekerra, and from 1118 to $1638 \mu \mathrm{S} / \mathrm{cm}$ in Wadi Saïda. The high values of EC can be explained by the presence of some minerals coming essentially from wastewater discharge such as chlorides $\left(\mathrm{Cl}^{-}\right)$and sulphates $\left(\mathrm{SO}_{4}{ }^{2-}\right)$, because they are the most dominant soluble salts on wastewater discharge for both wadis (Fig. 5). The average values of $\mathrm{Cl}^{-}$for this 
monitoring periods were in Wadi Mekerra: $549.25 \mathrm{mg} / \mathrm{l}$ in $\mathrm{M} 1,654.02 \mathrm{mg} / \mathrm{l}$ in $\mathrm{M} 2$, and $704.71 \mathrm{mg} / \mathrm{l}$ in M3.While, in Wadi Saïda the average values were: $175 \mathrm{mg} / \mathrm{l}$ in S1, $246 \mathrm{mg} / \mathrm{l}$ in S2, and $271.66 \mathrm{mg} / \mathrm{l}$ in S3. However, the average values of sulphates in the both wadis for the different periods revealed the presence of this chemical element with important contents exceeding the standard values recommended by NWRA (50-200 mg/l). The $\mathrm{SO}_{4}{ }^{2-}$ follows a gradient often progressive from upstream to downstream of flow direction, which can be explained by the influence of geological nature crossed by both wadis.
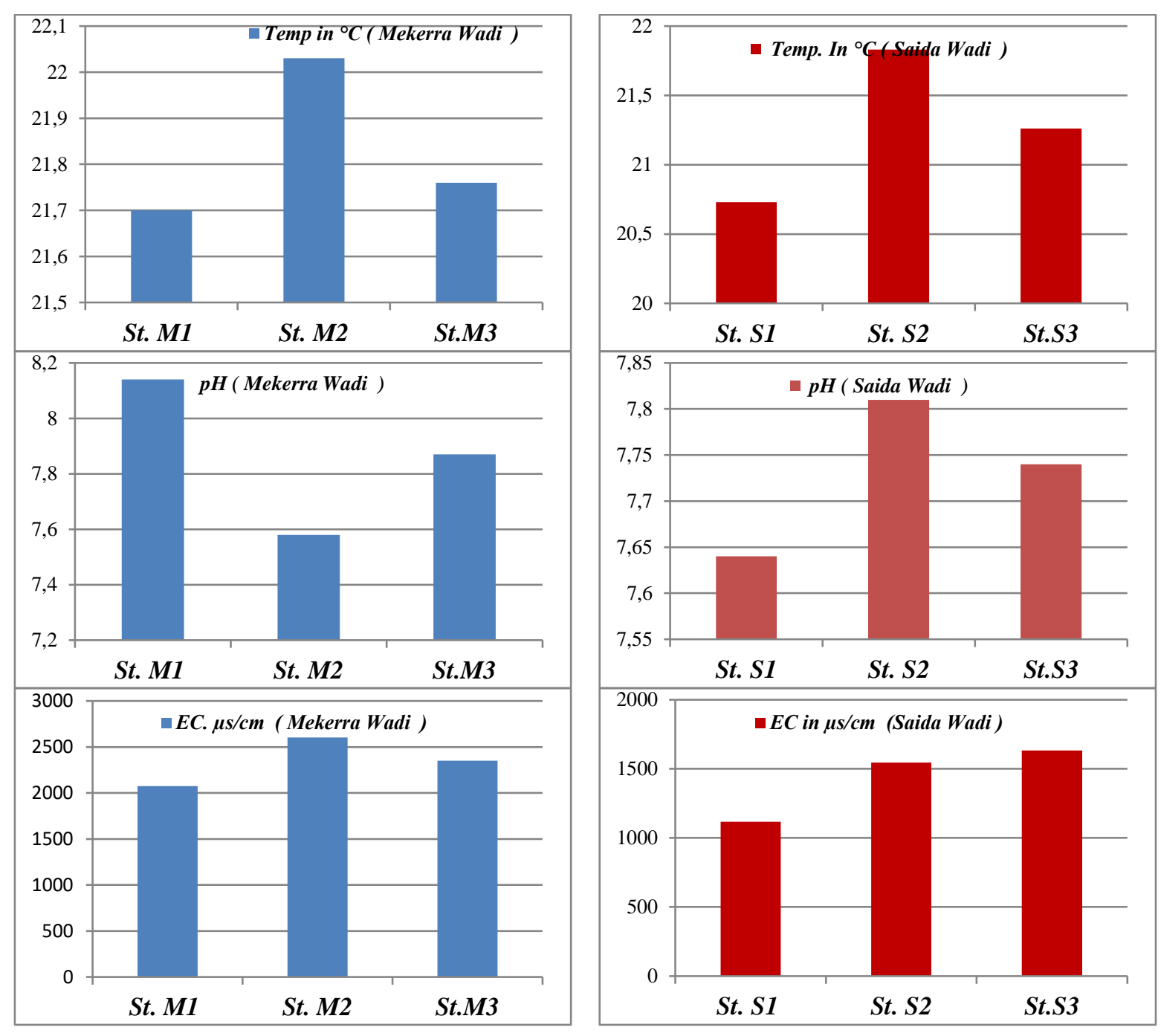

Figure. 4. Average value of undesirable elements of water in Mekerra and Saïda wadis.

Concerning water hardness elements, calcium $\left(\mathrm{Ca}^{2+}\right)$ and magnesium $\left(\mathrm{Mg}^{2+}\right)$, they showed an average values generally high (Fig. 5). The increase of $\mathrm{Ca}^{2+}$ and $\mathrm{Mg}^{2+}$ in the different studied points for each wadi may be explained by the geological nature crossed by both wadis, due to the presence of limestone and dolomite of Jurassic, and also the influence of solid and liquid discharges (leachate). The high mineralization represented by DR (Fig. 5) observed in both wadis, from 1804 to 2173 mg/l for wadi Mekerra, and 
from 990 to $1395 \mathrm{mg} / \mathrm{l}$ in wadi Saïda) can be explained by influence of the geological nature crossed by both wadis and also anthropogenic pollution.
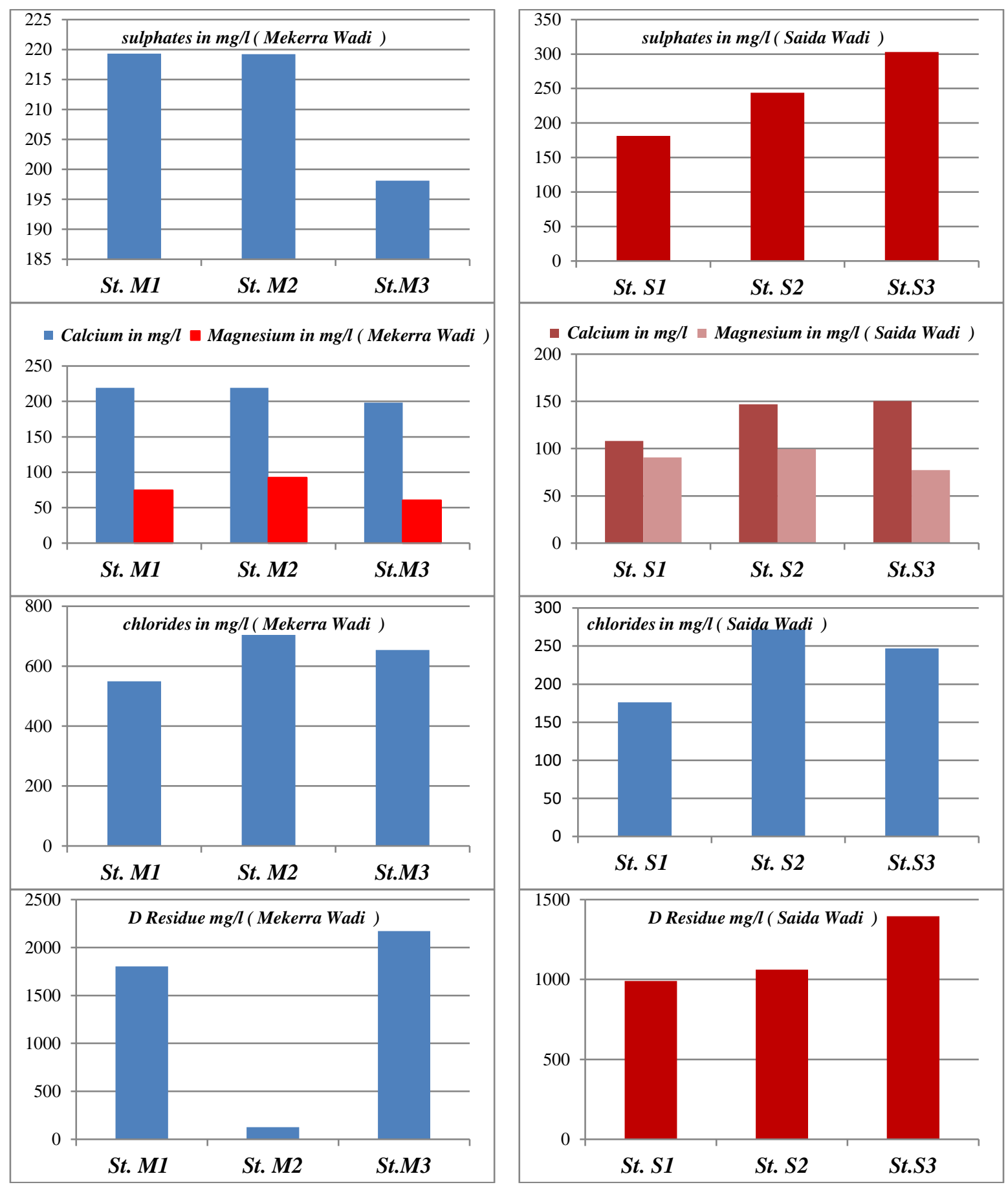

Figure 5. Average values of mineralization elements in Mekerra and Saïda wadis

The nitrate concentrations $\left(\mathrm{NO}_{3}{ }^{-}\right)$which exist naturally in water are generally ranged between 1-10 $\mathrm{mg} / \mathrm{l}$. While the results obtained in the studied areas show variable contents of $\mathrm{NO}_{3}{ }^{-}$(Fig. 6). So, the concentrations of nitrates in wadi Mekerra show a high value in the station M3 $(43.20 \mathrm{mg} / \mathrm{l})$. However, the concentrations of nitrates in wadi Saïda, show a decrease of nitrates from upstream to downstream, with a low value in S2. 
The presence of this chemical parameter in water values exceeding the authorized standards is due essentially to the influence of domestic discharges and agricultural fertilizers.

Regarding the nitrites ions $\left(\mathrm{NO}_{2}^{-}\right)$, (Fig. 6), the water samples in Mekerra wadi, indicate important values, with averages vary from $0.72 \mathrm{mg} \mathrm{NO}_{2}^{-} / \mathrm{l}$ in $\mathrm{M} 1$, to 2.11 $\mathrm{mg} \mathrm{NO} 2^{-} / \mathrm{l}$ in $\mathrm{M} 2$. This nitrites enrichment may be due to the impact of wastewater, essentially in the city centre of Sidi-Bel-Abbes (Graba quarter). However, in wadi Saïda, the results show an increasing of nitrites gradient, from downstream to upstream, and the average values are $0.5 \mathrm{mg} / \mathrm{l}$ in $\mathrm{S} 1,0.77 \mathrm{mg} / \mathrm{l}$ in $\mathrm{S} 2$, and $1,12 \mathrm{mg} / \mathrm{l}$ in $\mathrm{S} 3$. The evolution of $\mathrm{NO}_{2}{ }^{-}$is due to the influence of wastewater discharges, especially by organic matter in the flow direction of wadi Saïda.
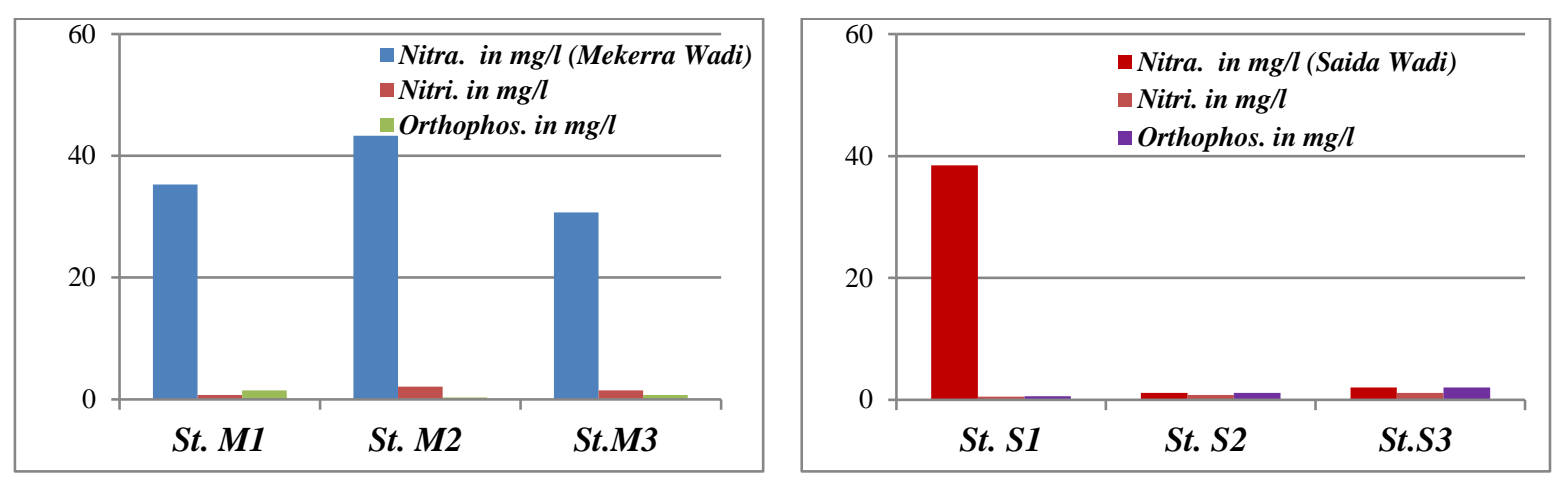

Figure 6. Average values of Nitrogen and phosphorus elements in Mekerra and Saïda wadis

The orthophosphates $\left(\mathrm{PO}_{4}^{3-}\right)$ come essentially from housing activities (wastewater) and from industrial and agriculture. When content of this chemical element exceed $0.1 \mathrm{mg} / \mathrm{l}$, can indicate water pollution (Laraba and Hadj Zoubir, 2009). The results of $\mathrm{PO}_{4}{ }^{3-}$ ions recorded in wadi Mekerra (Fig. 6) show an increase from upstream to downstream, with a light decrease in the city centre of Sidi-Bel-Abbes in the station M3 $(0.33 \mathrm{mg} / \mathrm{l})$. While, in the case of Saïda wadi, the values of $\mathrm{PO}_{4}{ }^{3-}$ (Fig. 6) show an increasing gradient from upstream to downstream ( $\mathrm{S} 1=0.5 \mathrm{mg} / \mathrm{l} ; \mathrm{S} 2=1.13 \mathrm{mg} / \mathrm{l}$; $\mathrm{S} 3=2.06 \mathrm{mg} / \mathrm{l}$ ). Based to Algerian standards (NWRA, 2009), surface water quality in both wadis are classified in the bad category.

The oxygen dissolved quantities of different samples in both wadis show average values (Fig. 7), generally, low than Algerian standards ( $>$ mg/l). They can be justified by the different spills load of organic matter along both wadis such as: wastewater, domestic discharges, animal manure, etc.

Concerning the biological oxygen demand ( $\mathrm{BOD}_{5}$ ), results obtained (Fig. 7) show high values, which can be due to the effect of different rejects, especially urban discharges reversed in both wadis.

Finally, physico-chemical results obtained show that water of both wadis (Mekerra and Saïda) crossed the cities of Sidi-Bel-Abbes and Saïda are classified in category of 
moderately polluted to heavily polluted compared to the Algerian standards of surface water (NWRA, 2009).
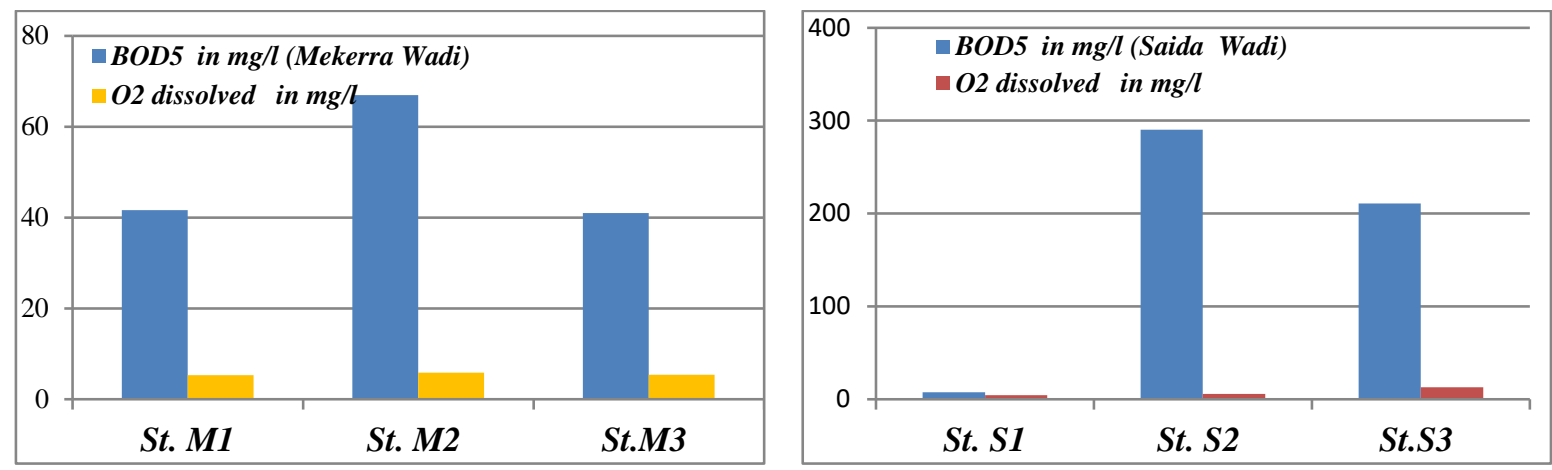

Figure 7. Average values of $\mathrm{BOD}_{5}$ and oxygen dissolved in Mekerra and Saïda wadis

\subsection{Assessment of microbiological contamination}

\subsubsection{Micro bacteriological parameters}

In fact, bacteriological analyses of water have as purpose to determine bacterial species which could present risks to human health (Aboulkacem et al., 2007). For the case of wadis Mekerra and Saïda, the results of the Total Aerobic Mesophilic Bacteria (TAMB) at $22^{\circ} \mathrm{C}$ and $37^{\circ} \mathrm{C}$ (Table 2) show generally an increase from upstream to downstream. The TAMB at $22{ }^{\circ} \mathrm{C}$ in wadi Mekkarra indicates a high values in the peripheral of the city, and a little decrease in the city centre of Sidi-Bel-Abbes $\left(2,34 \times 10^{4}\right.$ UFC/ $100 \mathrm{ml}$ ). However, at $37{ }^{\circ} \mathrm{C}$, the TAMB indicate an increase from upstream to downstream, the highest average value has been observed in station $M 3\left(1,13 \times 10^{5}\right.$ UFC $/ 100 \mathrm{ml}$ ). We can explain the augmentation of TAMB in this wadi by the effect of the increase of pollutant load. In wadi Saïda, the results of TAMG at $22^{\circ} \mathrm{C}$ and $37{ }^{\circ} \mathrm{C}$ show an increasing gradient from upstream towards downstream. Generally, total germs enumerated at $22{ }^{\circ} \mathrm{C}$ are mainly highest than those counted at $37^{\circ} \mathrm{C}$, which is probably due to the effect of indigenous (Aboulkcem et al., 2007). However, at $37^{\circ} \mathrm{C}$, the total germs of bacteria have an intestinal origin (human or animal) (El Haissoufi et al., 2011).

In term of faecal contamination, some inductors bacteria were used, and the results are summarized in the table 1 . The results show an increase of bacteria from upstream to downstream in both study areas; this is due to domestic waste, leaching from farmlands loaded with organic matter of animal origin and/or the direct discharge of livestock manure.

The experiment results relating to faecal streptococci (FS) of water of two wadis show an increase gradient from upstream to downstream for both study areas. These germs confirm the faecal pollution coming from human and animal origin. Loads in FS the most imploring are that located in station M2 with average value of $10^{2} / 100 \mathrm{ml}$ and 
in $\mathrm{M} 3\left(1,2 \times 10^{2} / 100 \mathrm{ml}\right)$. By contrast, the most noticed in wadi Saïda is in S2 $\left(1,36 \times 10^{5} / 50 \mathrm{ml}\right.$ in average) and S3 $\left(5,33 \times 10^{5} / 50 \mathrm{ml}\right.$ in average).

The origin of faecal pollution is carried out by the quantitative ratio between faecal coliforms (FC) and streptococci faecal (SF) (Tab. 1). When this ratio is upper than 4, it means human pollution of origin (coming from waste reject). However when it is low than 0.7 , it signifies an animal pollution of origin (coming from livestock, sheep). While when FC/SF is between 1 and 2, the origin is uncertain (BouSaad et al., 2007).

In the studied stations, the ratio values of water in both wadis indicate that the faecal pollution in wadi Mekkara is mainly coming from human origin (FC/SF > 4), which confirms the impact of wastewater on the surface water. However, the faecal pollution in wadi Saïda is coming mainly from animal origin ( $F C / S F<0.7)$.

Table 1 : Bacteriological analyses of water in wadis Mekerra and Saïda.

\begin{tabular}{|c|c|c|c|c|c|c|c|}
\hline \multirow{3}{*}{ Parameters } & \multirow{3}{*}{ Units } & \multicolumn{6}{|c|}{ Average values of three sampling points from 2011 to 2013} \\
\hline & & \multicolumn{3}{|c|}{ Wadi Mekerra } & \multicolumn{3}{|c|}{ Wadi Saïda } \\
\hline & & St. (M1) & St. (M2) & St. (M3) & St. (S1) & St. (S2) & St.(S3) \\
\hline TMAG at $22^{\circ} \mathrm{C}$ & UFC/ $100 \mathrm{ml}$ & $4,64 \times 10^{4}$ & $2,34 \times 10^{4}$ & $4,04 \times 10^{4}$ & $3,98 \times 10^{4}$ & $2,08 \times 10^{5}$ & $1,11 \times 10^{6}$ \\
\hline TMAG at $37^{\circ} \mathrm{C}$ & $\mathrm{UFC} / 100 \mathrm{ml}$ & $3,35 \times 10^{3}$ & $2 \times 10^{4}$ & $1,13 \times 10^{5}$ & $1,98 \times 10^{2}$ & $4,67 \times 10^{5}$ & $7,47 \times 10^{5}$ \\
\hline $\begin{array}{l}\text { Total coliforms } \\
\text { at } 37^{\circ} \mathrm{C}\end{array}$ & germs/100ml & $7,33 \times 10^{2}$ & $4,6 \times 10^{3}$ & $5,03 \times 10^{3}$ & $1,62 \times 10^{3}$ & $2,91 \times 10^{5}$ & $5,64 \times 10^{5}$ \\
\hline $\begin{array}{l}\text { Faecal coliforms } \\
\text { at } 37^{\circ} \mathrm{C}\end{array}$ & germs $/ 100 \mathrm{ml}$ & $2,33 \times 10^{2}$ & $4,5 \times 10^{2}$ & $5,33 \times 10^{2}$ & $1,86 \times 10^{2}$ & $2 \times 10^{3}$ & $6,46 \times 10^{4}$ \\
\hline $\begin{array}{l}\text { Streptococci } \\
\text { faecal at } 37^{\circ} \mathrm{C}\end{array}$ & germs $/ 100 \mathrm{ml}$ & $5,7 \times 10$ & $10^{2}$ & $1,2 \times 10^{2}$ & $3,20 \times 10^{2}$ & $1,36 \times 10^{5}$ & $5,33 \times 10^{5}$ \\
\hline $\mathrm{FC} / \mathrm{SF}$ & - & 4.09 & 4.5 & 4.4 & 0.58 & 0.01 & 0.12 \\
\hline
\end{tabular}

\subsubsection{Organic pollution index (OPI)}

Several chemical indices have been established to determine the water quality. In this work, we are used the OPI introduced by Leclercq and Marquet (1987) to assess the organic pollution degree, by using the principle pollutant elements such as: $\mathrm{BOD}_{5}$, Nitrites $\left(\mathrm{NO}_{2}^{-}\right)$, Phosphates $\left(\mathrm{PO}_{4}^{3-}\right)$, Ammonium $\left(\mathrm{NH}_{4}{ }^{+}\right)$, where they classified water quality into 5 categories. The results show that water quality of Mekerra wadi is characterized by a very high organic pollution from upstream to downstream.

On otherwise, in Saïda wadi, the organic pollution increases from upstream (high OPI), mainly during passage in the urban area of Saïda city, until downstream (very high OPI) (Tab. 2). 
Table 2. Organic Pollution Index (OPI) in wadis Mekerra and Saïda

\begin{tabular}{|c|c|c|c|}
\hline Name of Wadi & Station & OPI & Category and class \\
\hline & M1 & 1 & Very high organic pollution \\
\hline \multirow[t]{3}{*}{ Mekerra } & M2 & 1,33 & Very high organic pollution \\
\hline & M3 & 1,33 & Very high organic pollution \\
\hline & S1 & 2 & High organic pollution \\
\hline \multirow[t]{2}{*}{ Saïda } & S2 & 1 & Very high organic pollution \\
\hline & S3 & 1 & Very high organic pollution \\
\hline
\end{tabular}

\subsubsection{Microbiological contamination index (MCI)}

The microbiological contamination index is also used to determine the categories of faecal contamination. The calculation of MCI is based on the three pollutant elements (TC, FC and FS), which can be classed in one of the five classes (Leclercq 2001).

The evaluation of MCI for both wadis (Tab.3), show that water are exposed to the faecal contamination, but not with the same importance.

- In wadi Mekerra, the MCI shows that water is characterized by low to moderate faecal pollution, when it crosses the city of Sidi-Bel-Abbes;

- In wadi Saïda, the MCI shows the presence of faecal pollution, with increase from upstream to downstream in Saïda city. This difference in faecal contamination degree between the two cities can be due to injection of chemical disinfectant (lime), particularly in hot periods, for the area of Mekerra.

Table 3: Microbiological contamination index in Mekerra and Saïda wadis

\begin{tabular}{cccc}
\hline Name of wadi & Stations & MCI & \multicolumn{2}{c}{ Fecal contamination class } \\
& M1 & 3,66 & Low \\
Mekerra & M2 & 3,33 & Moderate \\
& M3 & 3,33 & Moderate \\
\hline & S1 & 4 & Low \\
Saïda & S2 & 2,33 & High \\
& S3 & 01 & Very high \\
\hline MCI $=$ Microbiological contamination Index by using 03 parameters : & \\
$M C I=4,3-5,0:$ zero faecal contamination & \\
$M C I=3,5-4,2:$ low faecal contamination & \\
$M C I=2,7-3,4:$ Moderate faecal contamination. & \\
$M C I=1,9-2,6:$ High faecal contamination & \\
$M C I=1,0-1,8:$ Very high faecal contamination & \\
\hline
\end{tabular}




\section{Conclusion}

It is important to examine the status of the water pollution in Wadis Mekerra and Saïda, in order to ensure their impact on the environment, mainly during the flow through urban zones of Sidi-Bel-Abbes and Saïda. These wadis constitute favorite places of wastewater discharges that come from the different agglomerations in these areas. The spatio-temporal monitoring of physico-chemical parameters shows clearly the existence of chemical and organic pollution in these watercourses where the concentrations of calcium, magnesium, chlorides, nitrates, nitrites, phosphates, $\mathrm{BOD}_{5}$ and dissolved oxygen exceed the recommended standards for surface water. They are confirmed by Micro bacteriological parameters, which show an increase from upstream to downstream in both areas, and by the increase of the organic pollution index (OPI). The bacteriological analyses indicate the existence of faecal contamination in the origin is human. The totals mesophilic germs are important at $22^{\circ} \mathrm{C}$ than that at $37^{\circ} \mathrm{C}$. Through these results, it is necessary to protect the health of inhabitants and to preserve environment in these areas. For this, we recommend a number of practices within the framework of sustainable management, with a view to preserving and rehabilitating these two wadis:

- Rehabilitates the sewerage networks and fight against black spots from the discharge of wastewater in the two wadis;

- Prohibits the discharge of solid wastes, including household garbage, construction residues, etc. ;

- Activates the process of collecting and treating wastewater not only within the two towns, Sidi-Bel-Abbes and Saïda, but also at all the watersheds of the two wadis;

- Regulates the use of agricultural fertilizers, nitrogen and phosphorus, as well as phytosanitary products in agriculture practiced in the two watersheds;

- Creation of input tracks for these two wadis to facilitate cleaning and surveillance;

- Disinfects the water at the two sites with lime (liming technique), especially during low water periods;

- In addition to pollution and the problem of degradation of the surface water quality, this seems to be mainly due to the phenomenon of erosion of watersheds, and siltation of these streams. It is very important to install a protection systems, and anti-erosion devices such as: retention benches, reforestation of mountain, etc. to deal with this problem and minimize the risk of pollution;

- Reactivation of legislative and regulatory processes, in particular, texts relating to the protection of water and the environment.

\section{References}

1. Aboulkacem A, Chahlaoui A, Soulaymani A, Rhazi-filali F, Benali D, (2007). Etude comparative de la qualitébactériologique des eaux des ouedsBoufekrane et Ouislane à la traversée de la ville de Meknès (Maroc),

2. Rev. Microbiol. Ind. San et Environn. N¹, pp. 10-22. 
3. Achahbar, N. (2020). Physicochemical and bacteriological quality assessment of spring waters in the Tetouan region (Morocco). Environmental and Water Sciences, public Health and Territorial Intelligence Journal, 4(3).

4. Benyahia, M., Bouzidi, M. A., Moueddene, K., Hallouche, B., Attaoui, I., Meliani, H., \&Dernouni, F. (2011). understanding of sidibel abbes plain flooding by mekerra river (west of algeria). revueljee $n^{\circ} 11,26-45$.

5. Bourek R., (2010). Modélisation pluie - débit. Application au bassin versant de la Mactaa (NW algérien), mémoire de magistère, université de Aboubkeur Belkaidtlemcen(Algérie),

6. Bouderbala, A. (2019a). The impact of climate change on groundwater resources in coastal aquifers: case of the alluvial aquifer of Mitidja in Algeria. Environmental Earth Sciences, 78(24): 698.

7. Bouderbala, A. (2019b). Human impact of septic tank effluent on groundwater quality in the rural area of Ain Soltane (Ain Defla), Algieria. Environmental \& Socio-economic Studies, 7(2), 1-9.

8. Boudoukha, A., Bouguerne, A., \&Mebarkia, A. (2014). Impact of climate change and human activity on water quality of the dam Ain Zada.Algeria. International Journal of Global Change, 2(3), 74-75.

9. Bremond and Perrodon, (1979). Parameters of water quality. Ministry of Environment, Pollution prevention directorate, France, 2nd edition, $259 \mathrm{p}$

10. DPPT (2011). Monograph of the wilaya of Saïda, $15 \mathrm{p}$.

11. El Haissoufi, H., Berrada, S., Merzouki, M., Aabouch, M., Bennani, L., Benlemlih, M., and Lalami, A. E. O. (2011). Pollution des eaux de puits de certains quartiers de la ville de Fès, Maroc. Rev. Microbiolol. Ind. san et Environn, 5(1), 37-68.

12. Karrouch, L., Chahlaoui, A., \&Essahale, A. (2017). Anthropogenic impacts on the distribution and biodiversity of benthic macroinvertebrates and water quality of the Boufekrane River, Meknes, Morocco. Journal of Geoscience and Environment Protection, 5(07), 173.

13. Kerkeb A., (2011). Diagnostic de la qualité de l'eaudistribuée dans la ville de Saïda (nord-ouest de l'Algérie) et problèmesrencontrés dans son réseaud'adductiond'eau potable, mémoire du magistère, Université DjilaliLiabes - Sidi Bel Abbés (Algérie), p136.

14. Guenfoud A., (2009). Management of water resources in the plain of Sidi Bel Abbés for sustainable development, master's thesis, DJILALI Liables-Sidi Bel Abbés University (Algeria),

15. Dahman M., (2016). hydrological and hydrogeological study of the watershed of Wadi Saïda, master's thesis, University of Oran 2

16. Khaldi, A. (2005). Impacts de la sécheresse sur le régime des écoulements souterrains dans les massifs calcaires de l'Ouest Algérien" Monts de Tlemcen-Saïda. These de doctorat, universitéd'Oran, Algérie. 132p.

17. Hachemaoui Ch., (2007). Etude et simulation de la variation et de la propagation de la pollution dans la nappe de Saïda, mémoire de magistère, université Stanbouli Mustapha Mascara(Algérie),

18. Laraba, A., \& Hadj Zobir, S. (2009). Pollution organique des eaux de I'OuedSeybouse (Plaine alluviale de Guelma, Nord-Est Algérien), N²3, 1-6.

19. Leclercq, L. (2001). Intérêt et limites des méthodesd'estimation de la qualité de l'eau. Station scientifique des Hautes-Fagnes: Belgique, 75. Available site: www.inforef.be/projets/eureau/.../introduction.htm

20. Maliki, S. B. E. (2006). Politique de I'eauenAlgérie: les modèlesmarchands face à la pauvreté. Research Gate, 97-106.

21. Meddi, M., Talia, A., \& Martin, C. (2009). Évolutionrécente des conditions climatiques et des écoulements sur le bassin versant de la Macta (Nord-Ouest de l'Algérie). Physio-Géo. Géographie physique et environnement, (Volume 3), 61-84.

22. NWRA (2009). Normative grid for estimating the generalquality of surface water, summary report , 40 Avenue Mohammedi - Bair Mourad Rais, Alegria , 15p.

23. Rodier .J. J. et al. , (2009). The analysis of water., 9th edition, Dunod, Paris. 1526 p. 
24. Saab, H., Nassif, N., El Samrani, A., Daoud, R., Medawar, S., \&Ouaïni, N. (2007). Suivi de la qualitébactériologique des eaux de surface (rivière Nahr Ibrahim, Liban). Revue des sciences de l'eau/Journal of Water Science, 20(4), 341-352.

25. Tahar, S. (2013). Impact des inondations sur l'espaceurbain, le cas de la wilaya de Sidi Bel Abbès, mémoire de magister, universitéd'ORAN $124 \mathrm{p}$. 